\title{
THE PRECIPITIN TEST FOR BLOOD IN FECES
}

\author{
Ludig Hettoen, Bernard Fantus
}

\author{
AND \\ Sidney A. PORTIS \\ From the John McCormick Institute for Infectious Diseases, Chicago
}

We have made a study of the precipitin test as applied to human feces. Fecal extracts were prepared in the following way:

Liquid feces were filtered directly by means of fine filter paper; semisolid or solid feces were mixed with $0.9 \%$ salt solution so as to obtain as concentrated an extract as possible and then filtered through a Buchner filter. If the extract was acid to litmus paper, it was neutralized with dilute sodium hydrate solution; if alkaline, by means of dilute hydrochloric acid. Chloroform was added to restrain bacterial growth. Clarification of the extract was secured by rapid centrifugation.

The precipitin tests were made in small, clear glass tubes, about $0.5 \mathrm{~cm}$. in diameter; a small quantity of extract was placed in the tube and about $0.1 \mathrm{~cm}$. of antihuman rabbit serum introduced at the bottom by means of a capillary pipet in such manner as to get a precise line of contact between the two fluids. The tubes were kept at room temperature and the results read after one hour. In most of the positive reactions there formed rather promptly a well defined precipitate in form of a grayish layer at the junction of the extract and the serum. As a rule the antihuman serum was. 12,000 in titer, that is, it would give a precipitate within 20 minutes at room temperature with dilution of human blood $1: 12,000$ in salt solution. The specimens of feces from patients under treatment were obtained from the service of Dr. B. W. Sippy in the Presbyterian Hospital and from the private practice of Dr. Milton M. Portis; most of the specimens were obtained from the latter source. The specimens from cases of pernicious anemia came from patients in various hospitals. The specimens from normal persons were mostly from young men in military training, the others from medical students.

Our results are given in Table 1 . In view of the fact that a positive result was obtained in such a large proportion of normal persons regardless of whether the Weber and benzidin tests were negative or positive, there is no necessity for any discussion of the possible value of the precipitin test in the diagnosis of occult blood in the feces. The only conceivable practical value of precipitin tests for human blood proteins in feces would be in cases giving a negative result with a precipitin test and a positive Weber or benzidin reaction. Under these circumstances a negative result with the precipitin test would indicate that the positive chemical test probably was not due to the presence of human blood. 
The extracts of feces from normal persons on unrestricted diet were tested also with antibeef, antiswine, antisheep and antichicken serums, but with practically uniformly negative results; in four instances only were not very strongly positive results noted, twice with antichicken serum and twice with antisheep serum.

TABLE - 1

Results of Precipitin Tests of Fecal Extracts

\begin{tabular}{|c|c|c|c|c|c|c|c|c|c|}
\hline \multicolumn{2}{|l|}{ Diagnosis } & \multicolumn{2}{|c|}{$\begin{array}{l}\text { Weber } \\
\text { Test }\end{array}$} & \multicolumn{2}{|c|}{$\begin{array}{l}\text { Benzidin } \\
\text { Test }\end{array}$} & \multicolumn{3}{|c|}{$\begin{array}{c}\text { Precipitin Test } \\
\text { (Antihuman Serum) }\end{array}$} & \multirow{2}{*}{ Remarks } \\
\hline Disease & $\left|\begin{array}{c}\text { No. } \\
\text { of } \\
\text { Cases }\end{array}\right|$ & $\begin{array}{c}\text { Nega- } \\
\text { tive }\end{array}$ & $\begin{array}{l}\text { Posi- } \\
\text { tive }\end{array}$ & $\mid \begin{array}{c}\text { Nega- } \\
\text { tive }\end{array}$ & Posi- & $\begin{array}{l}\text { Nega- } \\
\text { tive }\end{array}$ & $\mid \begin{array}{l}\text { Posi- } \\
\text { tive }\end{array}$ & $\begin{array}{l}\text { Per } \\
\text { Cent. } \\
\text { Posit. }\end{array}$ & \\
\hline $\begin{array}{l}\text { Normal.............. } \\
\text { Duodenal ulcer...... } \\
\text { Gastric ulcer......... } \\
\text { Cancer of esophagus } \\
\text { Cancer of stomach.. } \\
\text { Colitis................ } \\
\text { Cholecystitis....... } \\
\text { Cardiorenal disease. } \\
\text { Hyperthyroidism.... } \\
\text { Constipation........ } \\
\text { Gastric catarrh...... } \\
\text { Chronic appendicitis } \\
\text { Nephritis............. } \\
\text { Miscellaneous........ } \\
\text { Pernicious anemia... } \\
\text { (39 specimens) }\end{array}$ & $\begin{array}{r}58 \\
6 \\
4 \\
2 \\
2 \\
11 \\
9 \\
13 \\
14 \\
11 \\
7 \\
4 \\
10 \\
34 \\
16\end{array}$ & $\begin{array}{r}4 \\
4 \\
\ddot{1} \\
\ddot{9} \\
6 \\
12 \\
12 \\
9 \\
5 \\
4 \\
9 \\
20 \\
31\end{array}$ & $\begin{array}{r}54 \\
2 \\
4 \\
1 \\
2 \\
2 \\
3 \\
1 \\
2 \\
2 \\
2 \\
\dddot{1} \\
14 \\
8\end{array}$ & $\begin{array}{r}5 \\
5 \\
2 \\
1 \\
9 \\
9 \\
8 \\
12 \\
12 \\
10 \\
6 \\
3 \\
10 \\
27 \\
33\end{array}$ & $\begin{array}{r}53 \\
1 \\
2 \\
1 \\
2 \\
2 \\
1 \\
1 \\
2 \\
1 \\
1 \\
1 \\
\ddot{7} \\
6\end{array}$ & $\begin{array}{r}34 \\
2 \\
\ddot{1} \\
1 \\
4 \\
3 \\
5 \\
7 \\
8 \\
5 \\
2 \\
3 \\
20 \\
3\end{array}$ & $\begin{array}{r}24 \\
4 \\
4 \\
1 \\
1 \\
7 \\
6 \\
8 \\
7 \\
3 \\
2 \\
2 \\
7 \\
14 \\
36\end{array}$ & $\begin{array}{r}44 \\
66 \\
100 \\
50 \\
50 \\
63 \\
66 \\
61 \\
50 \\
27 \\
30 \\
50 \\
66 \\
41 \\
92\end{array}$ & $\begin{array}{l}\text { Unrestrieted diet } \\
\text { Restricted diet; no meat } \\
\text { Restricted diet; no meat } \\
\text { Restricted diet; no meat } \\
\text { Restricted diet; no meat } \\
\text { Restricted diet; no meat } \\
\text { Restricted diet; no meat } \\
\text { Restricted diet; no meat } \\
\text { Restricted diet; no meat } \\
\text { Restricted diet; no meat } \\
\text { Restricted diet; no meat } \\
\text { Restricted diet; no meat } \\
\text { Restricted diet; no meat } \\
\text { Restricted diet; no meat } \\
\text { Special diet and arsenic }\end{array}$ \\
\hline
\end{tabular}

These results are not in agreement with those of $\mathrm{Kretowski,}^{1}$ in whose hands the precipitin test with antihuman serum of fecal extracts gave negative results when the chemical tests for blood were negative, and who regards a positive result with antihuman serum as direct evidence of the presence in the feces of human blood. Kretowski, however, does not say anything about the strength of the serum used and he examined altogether only a small number of cases. Citron $^{2}$ did not obtain any positive results with antihuman serum and extracts of normal feces, but he also omits to say anything about the strength of the serum used. In all the cases of intestinal disturbances which he examined, the feces being diarrheal, he obtained positive results. Our observations also indicate that liquid and semiliquid feces give positive results with the precipitin tests more often than solid feces. The specimens examined from cases of pernicious anemia and which almost without exception gave positive results with the precipitin test were all or practically all liquid or semi-liquid.

1 Nowiny Lekarskie, 1911, 23, p. 193.

2 Arb. a. d. kais. Gesundhtsamte, 1911, 36, p. 358 
At this time we are not concerned with the work of Brezina ${ }^{3}$ and others, ${ }^{4}$ who studied the precipitinogenic action of the contents of different parts of the intestinal tract. They did not study the action of antihuman serum on extracts of human feces; they did find, however, that among the antigenic substances in feces were such as would cause precipitins for the proteins of human blood to develop in the animals, but these antigenic substances were not at all present in large quantities. Kraus and Wilenko ${ }^{5}$ failed to get any reaction in cholera stools with antihuman serum which gave reaction with the stools of enteritis, tuberculosis and nephritis. From this fact they conclude that the cholera stool consists mostly of water and salts, and contains little or no proteins.

\section{SUMMARY}

Extracts of feces in salt solution often contain substances that form precipitate with antihuman serum. This seems to be the case just about as often in the case of healthy young men as of persons with various diseases. Such substances may be present in extracts of feces that do not give chemical tests for blood, and it may be inferred that such substances may be human proteins derived partly from the blood and partly also from the cells lining the intestinal tract.

The precipitin test for human blood in feces can be of only limited practical value; if negative in the presence of positive chemical blood tests, the indication would be that the blood is not human.

Extracts of feces of healthy men on unrestricted, full meat diet, only very exceptionally give positive reaction with antibeef, antisheep, antiswine and antichicken serums, showing that in health foreign proteins taken into the stomach as a rule do not reach the feces as such.

In cases of pernicious anemia under treatment with arsenic the feces practically always give a positive reaction with antihuman serum.

3 Wien. klin. Wchnschr., 1907, 20, p. 560.

- Brezina and Ranzi: Wien. klin. Wchnschr., 1908, 21, p. 1524. Solma and Wilenko: Ztschr. f. Immunitätsf., O., 1909, 3, p. 1 .

- Wien. klin. Wchnschr., 1909, 21, p. 150. 